\title{
Slovenian Labour and Social Law in Relation to the EC Law
}

\author{
Barbara KRESAL
}

\section{Introduction}

In today's economy, which is becoming more and more globalized, labour and social law still remain mostly national. Even in the European Union (EU), the most advanced regional organisation in the world, the Community is not competent for issues like pay, freedom of association, strikes and other industrial action. Other important topics like social security, job security and workers participation are subject to the unanimity rule. ${ }^{1}$

However, within the EU it is constantly emphasised that sustainable economic growth goes hand in hand with social cohesion. »Existing international economic and social rules and structures are unbalanced at the global level. Global market governance has developed more quickly than global social governance. $\ll^{2}$ The European social model, based on flexicurity, aims at strengthening the social aspects of development strategies adequately. The EU is seen by many as an important international actor in preserving and developing further such a model, which tries to balance between economic and social interests and respects European social heritage as well. In this respect, the role of the Court of the European Communities (the European Court of Justice ECJ) may not be overlooked.

An important body of acquis communautaire has been developed in the field of labour and social law during the 50 years of European integration. There are many directives relating to labour relations and social security, addressing issues like prohibition of discrimination and the principle of equal treatment, collective dismissals, transfers of businesses and undertakings, protection of workers' claims in case of the employer's insolvency, protection of safety and health at work, etc. And the ECJ has issued many

1 Blanpain, R./Colluci, M. (2004): The Globalization of Labour Standards, Kluwer, The Hague, p. 15. Blanpain points out that there is no countervailing power, either regional or international, to transnational economic decision-making. And national states remain weak in this regard. Casale, for instance, speaks about »the progressive erosion of state sovereignty«. Global economic integration weakens government's intervention in macro-economic and social policies; states are competing to offer transnational economic actors the best tax, legislative and social conditions to attract investment. (Casale, G. (2005): Globalization, Labour Law and Industrial Relations - Some Reflections, In: Blanpain (ed.): Confronting Globalization, The Quest for a Social Agenda, Kluwer, The Hague, p.39-40).

2 EU Commission (2005): Promoting Core Labour Standards and Improving Social Governance in the Context of Globalization, In: Blanpain (ed.): Confronting Globalization, The Quest for a Social Agenda, Kluwer, The Hague, p. 55-56. 
important judgements in this field of law which consequently influenced the development of labour and social law within the Member States as well as at the Community level. ${ }^{3}$ Simitis stresses that "(r)ather than being a simple executor, the Court continues and complements the regulatory process initiated by the Treaty. It is through this ceaseless restatement of the original rules that the Court achieves its 'creative' appropriation of the Treaty." 4

In this context, the question about the relationship between the national labour and social law and the EC law in this field is of a particular importance. 5

The interaction between the national law (labour and social law, for instance, as well as any other field of law) and the EC law may occur in different ways. The discussion on the impact of the EC law on the national labour and social law is common, whereas the discussion on the impact of the national labour and social law on the EC law can sometimes also be provocative.

3 Sciarra emphasises the importance of the ECJ in this process and at the same time the interaction between the ECJ and the 'community of courts' (national courts within the European legal system). "The ECJ has been driven by national courts in addressing central points of Community law: direct effect, supremacy, the protection of fundamental rights, common market and competition rules and the social dimension. ... ECJ rulings, when set in motion by national preliminary references, are intended first and foremost to provide an answer to the specific questions put by the referring courts. However, the Court's power to penetrate domestic legal systems has, over the years, proved to be more pervasive and at times more challenging than mere compliance with supranational law might have implied. ... the words of the ECJ are spoken loudly and listened to very carefully, even by those who are not direct interlocutors."(Sciarra, S. (2001): Integration Through Courts: Article 177 as a Pre-federal Device, In: Sciarra, S. (ed.): Labour Law in the Courts, National Judges and the European Court of Justice, Hart Publishing, Oxford, p. 1-30). Many authors point out the important role of the ECJ for the development of the European labour and social law (Malmberg, J. et al. (2003): Effective Enforcement of EC Labour Law, Kluwer, The Hague, s. 28, 37; Blanpain, R. (2006): European Labour Law, Kluwer, The Hague, p. 73-81); Barnard, C. (2000): EC Employment Law, Oxford University Press, Oxford, p. 28-36; Heide, I. (2004): Gender Roles and Sex Equality - European Solutions to Social Security Disputes, ILO, Geneva, p. 14-17; Simitis, S. (2001): The Complexities of Living With and Interpretation Prerogative - Some Observations on an Imperfect Dialogue, In: Sciarra, S. (ed.): Labour Law in the Courts, National Judges and the European Court of Justice, Hart Publishing, Oxford, p. 291-300; Bercusson, B. (2005): Social and Labour Rights under the EU Constitution, In: De Búrca, G./De Witte, B. (ed.): Social Rights in Europe, Oxford University Press, Oxford, p. 170, 176-183; and others).

4 Simitis (2001), p. 292.

5 Beside the European Union, the International Labour Organisation (ILO) with its conventions and recommendations and the Council of Europe (CE) with its European Social Charter (and similar organisations in other regions) are the relevant international actors in the development of labour and social law. The relationship between the EC law in this field and the fundamental social rights guaranteed by the ILO's and the CE's legal instruments is also an important, yet sometimes delicate issue, but it will not be dealt with further in this article. Here, I shall only point out the question of the possible ratification of the European Social Charter (revised), together with the European Convention of Human Rights, by the European Union. For more see De Schutter, O. (2005): Anchoring the European Union to the European Social Charter - the Case for Accession, In: De Búrca, G./De Witte, B. (ed.): Social Rights in Europe, Oxford University Press, Oxford, p. 111-152. 


\section{The process of harmonisation of the Slovenian labour and social law with the requirements of the EC law}

In Slovenia, who became a Member State of the EU only three years ago, on 1 May 2004, the reflection about the impact of national labour and social law on the EC law is not usual, but something new, even unthinkable. The EC law is considered as an imperative, according to which Slovenian legal regulation is to be adapted, also in the field of labour and social law (of course, only regarding the issues which are subject of the EC legal rules).

In Slovenia, the last fifteen years (since the state independence and the change of the political and socio-economic system in the beginnings of 1990's) have been marked with the consistent changes of the entire legal order, one of the main characteristics of that process being the requirement that the legal regulation has to be harmonised with the EC law, with the entire acquis communautaire.

The systematic harmonisation of the Slovenian legal system began in 1993 when the Standing orders of the Government of the Republic of Slovenia laid down the obligation that every draft act, or amendment thereof, be explained as regards its compliance with pertinent EC regulations and directives, with the goal of assuring, as near as possible, conformity with the existing EC law. Končar points out that such an approach was based on the belief that the adoption of such solutions would also facilitate the goal set, namely, transition into market economy. ${ }^{6}$

This requirement was important when preparing new labour legislation, which was enacted in 2002 and came into force 1 January $2003 .{ }^{7}$ Proposed solutions had to be in accordance with the relevant EC directives in the field of labour law and social security. Requirements stemming from the EC law were a very important (sometimes decisive) factor in argumentation of the proposed solutions.

Harmonisation process has sometimes led to the introduction of new institutions not known before in the Slovenian labour law system, to the adoption of explicit legal provisions relating to the principles already acknowledged in the legal system or to more detailed and precise regulation of respective rights and obligations. The transposition of the EC law has already caused difficulties in the implementation of adopted new rules in certain cases (for instance, the regulation of working time). Not only the adopted directives, but also proposals of directives which up until now did not obtain support from the EU Member States were taken into consideration, when adopting the new Employ-

6 Končar, P. (2006): Slovenian Labour Law and European Integration, Transition Studies Review, May 2006, Vol. 13, No. 1, p. 38 (http://www.springerlink.com/media/1exdm0d7nm7wrma13mfk/ contributions/c/1/7/4/c174px38n36110m7.pdf).

7 Employment Relationships Act (Zakon o delovnih razmerjih, Official Journal of the Republic of Slovenia, No. 42/2002). 
ment Relationships Act in 2002 (in this regard, a regulation of temporary employment agencies can be mentioned). ${ }^{8}$

In this process, the case-law of the ECJ has been considered, too. Legal theory has analysed many important judgements of the ECJ which are relevant in the field of labour law and social security. In the period before the accession of Slovenia to the EU, the courts in Slovenia, including labour and social courts, have paid a lot of attention to the EC law and the ECJ within their training and educational programmes. Special attention was given to the issue of the preliminary ruling proceedings and the role of national courts in this regard. Labour and social courts were aware that they, too, would have to follow the decisions of the ECJ from the day of full membership of Slovenia in the EU on and that they would have to use the mechanism of the preliminary rulings in many cases, brought before labour and social courts after the accession of Slovenia to the EU.

Considering all that, it is understandable that there has been no real discussion in Slovenia on the possible ways in which the national labour and social law could influence the EC law. The EC law and the case-law of the ECJ have been considered as something already determined and defined, not as a variable. The variable in this relationship was considered to be Slovenian domestic law, which had to be adapted, harmonised with the requirements of the EC law.

\section{Interaction between the national law and the EC law?}

Mostly as a consequence of the requirements of the EC law, the following was among others - introduced into the new Employment Relationships Act in 2002:

- Provisions on the prohibition of discrimination regarding the access to the employment, during the employment relationship and in relation to the termination of employment relationship on the basis of different personal circumstances, in particular prohibition of discrimination on the basis of sex; the rule on equal treatment; the rule on equal pay for equal work or work of equal value for women and men; 9

- Provisions on the protection of workers in cases of transfer of undertakings or businesses or parts of undertakings or businesses;

8 Končar, p. 39.

9 Končar stresses that before the harmonisation with the equality directives Slovenian labour legislation did not contain any explicit provisions prohibiting discrimination in employment relationships, nor did it have any explicit provisions on equal pay. The protection against discrimination in employment was guaranteed by direct application of relevant constitutional provisions and international conventions (Končar, P. (2002): Le droit social en Slovénie au regard de l'acquis communautaire, Bulletin de droit comparé du travail et de la sécurité sociale, Université MontesquieuBordeaux IV, Pessac Cedex, p. 186-187). 
- provisions on the additional requirements in cases of collective dismissals;

- provisions requiring written contract of employment stating certain basic information about the employer and the employment relationship,

- etc.

Following the requirements of the EC directive on parental leave, a paternity leave was introduced into the new legislation on parental protection in $2001 .{ }^{10}$ In 1997, the legislation on guaranty fund and the rights of workers in case of insolvency of their employer was passed, the argumentation being also the requirements of the relevant EC directive. ${ }^{11}$ There are more such examples.

Allow me to comment on one example. As already said, Slovenian labour legislation neither had explicit provisions on the prohibition of discrimination and the principle of equal treatment of women and men in the field of labour law, nor on the principle of equal pay. Such provisions were introduced into the Slovenian labour legislation as a result of the harmonisation with the EC law. It could be thus concluded that before joining the EU, Slovenia did not pay enough attention to these issues and that the principle of equal treatment of women and men, including the principle of equal pay, was not implemented effectively. Such assumption would be incorrect. 12

Slovenia is one of the Member States with the lowest pay gap between women and men $(8 \%)$, one of the rare Member States, which have already reached (and even exceeded) the Lisbon employment target of $60 \%$ employment rate of women, and it is on the first place regarding the employment rate of women who have children (near $85 \%) ; 13$ besides, the problem of indirect discrimination of women who work part-time,

10 Paternity leave has been introduced into Slovenian legal order by the Parental Protection and Family Benefits Act (Zakon o starševskem varstvu in družinskih prejemkih, Official Journal of the Republic of Slovenia, Nos. 110/06 - consolidated text, 114/06). Enacted in 2001, it has been gradually put into force, so as the fathers are entitled to the paternity leave in the full length of 90 days since $1 \mathrm{Ja}-$ nuary 2005 (only 15 days are covered by the full pay compensation, for the rest, i.e. 75 days, the state is obliged to cover the payment of social security contributions, based on the level of the national minimum wage).

11 Public Guarantee and Maintenance Fund of the Republic of Slovenia Act (Zakon o Javnem jamstvenem in preživninskem skladu Republike Slovenije, Official Journal of the Republic of Slovenia, No. 78/06-consolidated text).

12 Končar emphasises that the equality principle was of a particular importance during the entire period after the second world war (Končar, P. (2002), p. 186).

13 Slovenia is also the only EU Member State in which the employment rate of women who have children is higher than the employment rate of women without children. Namely, in all other EU Member States there is a big difference between women and men in this regard: fewer women who have children are employed than those without them, whereas, for men, in all EU Member States the opposite is true - their employment rate is higher for men who have children than for men without children. This is an important indicator of the equality between women and men and it shows how important the issue of reconciliation of family and work responsibilities is in this regard (European Commission (2006): Holding a job - Having a life, Office for Official Publications of the European Communities, Luxembourg; European Commission (2007): Report on equality between women and men - 2007, Office for Official Publications of the European Communities, Luxembourg). 
has not (yet?) occurred in Slovenia, whereas it is well known in other EU Member States and also in the case-law of the ECJ. ${ }^{14}$

Besides, Slovenia has one of the most favourable regulations on parental leaves, be it from the point of view of the equal opportunities for women and men or the height of the benefits during the parental leave (in general, parents are entitled to one year's leave with a $100 \%$ wage compensation benefit). That is, consequently, one of the important factors for better opportunities of women in the labour market and for the reducing of the gender pay gap.

Considering all that, how should one evaluate the relationship between the national law and the EC law? Which law has or should have the relevant impact on the other and how? In this regard, the rule on the minimum requirements is very important, stating that the Member States can maintain or introduce more favourable provisions for workers then set out in the directive and that the implementation of the directive may not constitute a valid ground for reducing the level of protection already afforded to the workers.

Nevertheless, the question still remains whether and if so, how could the Slovenian labour law standards influence the general minimum level of rights within the EC law, be it in the way of the content of the given directive or in the way of an adequate interpretation of the given directive by the ECJ, which could improve actual (not just formal) possibilities for maintaining a certain level of employees' rights in Slovenia.

\section{Slovenian labour and social courts and the preliminary ruling proceed- ings}

I will continue with the same example - discrimination in employment. The requirements of the EC law regarding the antidiscrimination policy in the field of labour law, due to which the Slovenian labour legislation introduced special provisions on prohibition of discrimination, can be a very important factor for further development of Slovenian labour and social law. They offer the possibilities, legal instruments, which just have to be applied. The problem is, namely, that so far there have been almost no cases before the Slovenian labour courts which would open the question of discrimination in employment, equal treatment of women and men, equal pay, etc..

14 In Slovenia, the share of part-time workers in total employment is low $(6,5 \%)$ and there is only a minimal difference between women's and men's rates (5\% for men and 8,2 for women), whereas in many EU Member States part-time workers are predominantly women. In the entire EU, the total share of part-time workers is $17,7 \%, 7 \%$ for men and $31,4 \%$ for women. All data refer to 2004 ( $\mathrm{Ja}$ vornik, J. (ed.) (2007): Social Overview 2006, Institute of Macroeconomic Analysis and Development, Ljubljana, p. 90). 
When workers start to exercise their rights in this regard (and other rights stemming from the acquis communautaire), ${ }^{15}$ and when, consequently, the Slovenian labour and social courts have the opportunity to give judgements on these issues, the interaction between the national (Slovenian) labour and social law and the EC law in this field will occur. Requirements of the EC law will influence our legal reality, whereby the interpretations of the EC law by the ECJ should play an important role.

An important role should further go to the Slovenian labour and social courts. When applying EC legal rules, the Slovenian labour and social courts should also consider the national context, Slovenian legal reality and the respective labour and social law rules; all these may also influence the interpretation of the EC legal rules by the ECJ when deciding on the basis of the reference for a preliminary ruling submitted by the Slovenian courts. ${ }^{16}$ Besides, it is the national judges who remain responsible for settling the dispute which originated the reference, and in the end it is they who will have to decide the case. ${ }^{17}$

Pescatore stresses that " $(\mathrm{j})$ udicial interpretation of Community law is a creative process, whether it serves the purpose of consolidating unstable legal principles, clarifying them or favouring further developments". 18 "A judge is not alone in the Community system: there is ever-growing responsibility towards other judges and a need to develop common interpretative criteria. Co-operation is an essential part of such a unique system of adjudication, in which each national court must preserve its own linguistic and cultural identity and yet be aware of belonging to a community of courts". ${ }^{19}$

Sciarra further elaborates: "In all circumstances, be they the recipients of Community law or those who seek clarification on its enforcement, national courts place themselves at the centre of an inborn and yet unpredictable institutional equilibrium. They are the

15 Certain issues from EC labour and social law have already acquired more attention. For instance, claimants often refer to the EC law in cases dealing with the employees' rights in cases of transfers, collective redundancies or abuses of fixed-term contracts of employment.

16 Of course, there are limits. Simitis mentions 'the domestication' of the ECJ in relation to the comparative approach in the interpretation process of the ECJ. According to Simitis, in order to delimit and reduce the ECJ's power, "the demand that all interpretation efforts should be based on an extensive comparative approach was put forward ... the Court was expected to take the national laws as a starting-point and first and foremost to find out how they reacted to the issue at stake. They were seen as a filter through which the ECJ's argumentation had to pass in every case." (Simitis (2001), p. 297).

17 Questions referred for a preliminary ruling must be limited to the interpretation or validity of a provision of Community law, since the ECJ does not have jurisdiction to interpret national law or asses its validity.

18 Pescatore, P. (1986): Il renvio pregiudiziale di cui all'Art. 177 del Trattato CEE e la cooperazione tra la corte ed i giudici nazionali, Il foro italiano 1986, V, p. 26 (quoted by Sciarra (2001), p. 1).

19 Ibidem. In relation to the expression 'community of courts' Sciarra quotes Kilpatrick, C. (1998): Community or Communities of Courts in European Integration, European Law Journal, 1998, p. 121. 
vehicle for insinuating supranational norms into domestic systems and at the same time those who may vigorously, albeit indirectly, suggest the adaptation of national laws." 20

Condition sine qua non for this delicate, yet constructive and innovative interaction between national and EC law is that the Slovenian labour and social courts really start to use this instrument and start to make references for a preliminary ruling. Only then, the interaction between the Slovenian labour and social law and the EC law in this field will be possible.

For the time being, Slovenian labour and social courts do not yet use a reference for a preliminary ruling as a regular means within the court proceedings. Up until now, neither the Slovenian Supreme Court (Department for labour and social disputes) nor the Higher Labour and Social Court nor the labour and social courts of first instance have submitted any reference for a preliminary ruling yet. ${ }^{21}$ This is necessary and the approach of Slovenian labour and social courts towards this issue will have to be changed in the future. As Bruun already emphasised in his chapter of this book, the evolution of EC law occurs through an interaction between Community legislation and court practice and between national and EC law.

\section{$V$. The role of the EC law and the case-law of the ECJ in the case-law of Slovenian labour and social courts}

How often do the Slovenian labour and social courts refer to the EC legal rules and/or to the case-law of the ECJ in the reasoning of their decisions?

In the database of the Supreme Court of the Republic of Slovenia, only five judgements of the Department for labour and social disputes refer to the EC law: one of them dates back to the time before the accession of Slovenia to the EU, whereas the other four judgements refer to the EC directive on certain aspects of organisation of working time. $^{22}$ In the database of the Higher Labour and Social Court, there are a few more judgements which mention the EC law: they refer to the EC directive on fixed-term contracts, to the EC directive on transfers, to the EC directive on collective redundan-

20 Sciarra (2001), p. 4

21 Bruun describes similar characteristics for Finland and Sweden after their accession to the EU. Their courts have also been relatively restrictive in deciding when to submit such reference. " ... the national courts of last resort do not request preliminary rulings to the extent that might be expected. ...they avoid doing so wherever they can. During the period 1995-2003 the Swedish and Finnish courts of last resort have requested preliminary rulings on four and five occasions respectively..." (Bruun, N. (2006): Ten Years within the EU - Labour Law in Sweden and Finland following EU Accession, Swedish Studies in European Law, p. 85, 88).

22 Database at www.sodnapraksa.si (judgements of the Supreme Court, Nos. VIII Ips 45/2001, VIII Ips 79/2004, VIII Ips 37/2005, VIII Ips 216/2005 and VIII Ips 221/2005). 
cies and to the EC directive on protection of pregnant women workers. 23 Only one judgement in the database of the Higher Labour and Social Court refers in its reasoning to the case-law of the ECJ; the issue at stake was a transfer of undertaking. ${ }^{24}$

There are some judgements of the Constitutional Court of the Republic of Slovenia, dealing with labour and/or social issues, which refer to the relevant EC directives and to the relevant case-law of the ECJ. One such judgement deals with a social security issue, namely a different retirement age set for men and women for the acquisition of their rights to the old-age pension. ${ }^{25}$ Another judgement of the Constitutional Court deals with the prohibition of discrimination based on sex when dismissing an employee in connection to the retirement age, which is set differently for men and for women. ${ }^{26}$ It is also worth to mention the judgement of the Constitutional Court dealing with the on-call service provided by doctors in hospitals. 27

23 www.sodnapraksa.si. For instance, judgements of the Higher Labour and Social Court, Nos. Pdp 451/2006, Pdp 1519/2004, Pdp 1205/2004, Pdp 345/2004, Pdp 954/2005, Pdp 1174/2003, Pdp $1760 / 2003$.

24 www.sodnapraksa.si. Judgement of the Higher Labour and Social Court, No. Pdp 954/2005, 3. 3. 2006 (the following judgements of the ECJ were used: Spijkers, Case No. 24/85; Schmidt, Case No. 392/92; Merckx, Cases Nos. 171/94 and 172/94).

25 Judgement of the Constitutional Court, No. 298/96, 11. 11. 1999 (Official Journal of the Republic of Slovenia, No. 98/99): “...in Slovenia as in the framework of EU and elsewhere in the world, the goal of enforcing the principle of the equal treatment of men and women is universally accepted... However, this goal cannot be achieved only by declaring equality and simply over the night. As asserted by the National Assembly and the Government, also the EC legislation in the area of social security prescribes a gradual introduction of this principle. ... Council Directive No. 79/7/EEC on the gradual introduction (realization) of the principle of the equal treatment of men and women in cases of social security in its title demonstrates that the matter concerns the gradual introduction of the equality of men and women in determining conditions for the exercise of the rights arising under the statutory systems of social security. ... Social development brings changes also to the area of relationships between the sexes thereby requiring the abolishment of inequalities between them. Insofar as the differences between the sexes in actual life do not exist anymore, or are substantially reduced, there exists no need anymore for a different statutory regulation...".

26 Judgement of the Constitutional Court, No. 49/98, 25. 11. 1999 (Official Journal of the Republic of Slovenia, No. 101/99): "The EC Directive ... does not prevent the determination of a different age for the retirement of men and women. This also follows from decisions by the Court of Justice of the European Communities in Luxembourg. In the case brought to the Court by the Belgium Court of Cassation (joined cases C-377/96 to 384/96) it decided on 30 April 1998 that it is not inconsistent with Directive 79/7/EEC that a national legislation prescribes a different manner of the assessment of a pension following a different age prescribed for retirement with regard to sex. However, in Case No. C-137/94, dated 19 October 1995, it decided that Art. 7 of Directive 79/7/EEC does not allow the States which had determined, following this provision, a different age for the retirement of men and women, to apply such differentiation in other areas...".

27 Judgement of the Constitutional Court, No. 321/02, 27. 5. 2004 (Official Journal of the Republic of Slovenia, No. 62/04) refers to the EC directive on working time and to the judgements of the ECJ in the cases Simap (No. C-303/98) and Jaeger (No. C-151/02). 


\section{The internal market rules and the Community competition rules in rela- tion to the national labour and social law}

Considering that the competence of the EC in the field of labour and social law is rather restricted and therefore the Community legislation directly regulating labour and social relations is not so comprehensive, the "indirect" regulation in the field of labour and social law is getting more and more important. What $I$ have in mind are the internal market rules and the Community competition rules, which may (and do) to a certain extent interfere with the national labour and social regulation.

Fundamental questions are the following: where are the limits of such interferences, if and how much can these rules interfere with the national legal rules in the field of labour and social law?28

If, regarding a certain issue of labour or social law, the Community has no competence to regulate it, then, it may not indirectly, through other rules, influence the national regulation of this issue either. It is rather simple to explain this rule on the theoretical level, but in practice it is very difficult to draw a line.

Also from the point of view of the Slovenian legal and constitutional standards regarding labour relations, including the freedom of association, freedom of collective bargaining and the right to strike, the issues which are raised in the cases Viking and Laval are extremely delicate. ${ }^{29}$

The Slovenian Constitution guaranties freedom of association, including freedom of collective bargaining, and the right to strike. According to Article 77 of the Slovenian Constitution, the right to strike may be restricted only by law, if so required by the public interest, with due consideration given to the type and nature of the activity involved. Industrial action of the trade-unions can only be restricted upon criteria which are within the limits defined by the Constitution. National regulations of labour and social relations in Member States, including especially the constitutional rules in this field and the requirements developed in this regard by the case-law of the Constitutional Courts of the Member States have to be considered.

I would just mention (but not further elaborate) the question of relationship between the national legal order and the EC legal order in cases involving the constitutional issues, the question of relationship between the national Constitutions and the EC law, the

28 About this question see, for instance, Löwisch, M. (2007): Labour and Social Law in the EU Competition Policies, Transition Studies Review, Vol. 13, No. 1, Springer, Vienna, p. 40-43.

29 The International Transport Workers' Federation and The Finnish Seamen's Union v. Viking Line ABP and OÜ Viking Line Eesti (Case No. C-438/05; the opinion of Advocate General Maduro, 23. 5. 2007); Laval un Partneri Ltd v. Svenska Byggnadsarbetareförbundet and Others (Case No. C341/05; the opinion of Advocate General Mengozzi, 23. 5. 2007) - from database of the ECJ at www.curia.europa.eu. 
question of relationship between the national Constitutional Courts and the ECJ; all these questions are well known and very important. ${ }^{30}$

It has to be borne in mind that freedom of association, autonomy of collective bargaining and the right to strike are fundamental in the field of labour law. They are fundamental in the European industrial relations systems, emphasising social dialogue, as well as at the international level. As already pointed out by Bercusson in his article in this book, consideration of the ILO standards in this field by the ECJ would also be the right approach which reconciles respect for the international standards with the specific context of the acquis communautaire social.

\section{Conclusion}

From the beginning of the European integration the ECJ has been an important actor in the evolution of the EC labour and social law. At the same time, national courts dealing with labour and social disputes have important role in this regard as well, especially as the ones initiating preliminary rulings' procedures and which are, in this framework, the carriers of the impact of the national labour and social law on the law of the European Community. The EC law, in the field of labour and social law as well as in any other field, can not develop further (and has - in the past - not been developed) without the context and the adequate influence of the national law of the Member States.

\section{BIBLIOGRAPHY}

Barnard, C. (2000): EC Employment Law, Oxford University Press, Oxford.

Bercusson, B. (2005): Social and Labour Rights under the EU Constitution, In: De Búrca, G./De Witte, B. (ed.): Social Rights in Europe, Oxford University Press, Oxford, p. 167-197.

Blanpain, R. (2006): European Labour Law, Kluwer, The Hague, p. 73-81.

Blanpain, R./Colluci, M. (2004): The Globalization of Labour Standards, Kluwer, The Hague.

Bruun, $N$. (2006): Ten Years within the EU - Labour Law in Sweden and Finland following EU Accession, Swedish Studies in European Law, p. 59-96.

Casale, G. (2005): Globalization, Labour Law and Industrial Relations - Some Reflections, In: Blanpain (ed.): Confronting Globalization, The Quest for a Social Agenda, Kluwer, The Hague, p. 37-54.

De Schutter, O. (2005): Anchoring the European Union to the European Social Charter - the Case for Accession, In: De Búrca, G./De Witte, B. (ed.): Social Rights in Europe, Oxford University Press, Oxford, p. 111-152.

30 Many authors analyse the relationship between the ECJ and the Constitutional Courts of the MemberStates; see for instance Simitis (2001), p. 293-297. 
European Commission (2007): Report on equality between women and men - 2007, Office for Official Publications of the European Communities, Luxembourg.

European Commission (2005): Promoting Core Labour Standards and Improving Social Governance in the Context of Globalization, In: Blanpain (ed.): Confronting Globalization, The Quest for a Social Agenda, Kluwer, The Hague, p. 55-78.

Javornik, J. (ed.) (2007): Social Overview 2006, Institute of Macroeconomic Analysis and Development, Ljubljana.

Končar, P. (2006): Slovenian Labour Law and European Integration, Transition Studies Review, May 2006, Vol. 13, No. 1, p. 38-40,

(http://www.springerlink.com/media/1exdm0d7nm7wrma13mfk/contributions/c/1/7/4/c174px38n3 $6110 \mathrm{~m} 7 . \mathrm{pdf})$.

Končar, P. (2002): Le droit social en Slovénie au regard de l'acquis communautaire, Bulletin de droit comparé du travail et de la sécurité sociale, Université Montesquieu-Bordeaux IV, Pessac Cedex, p. $175-192$.

Löwisch, M. (2007): Labour and Social Law in the EU Competition Policies, Transition Studies Review, Vol. 13, No. 1, Springer, Vienna, p. 40-43.

Malmberg, J. et al. (2003): Effective Enforcement of EC Labour Law, Kluwer, The Hague, s. 28, 37.

Sciarra, S. (2001): Integration Through Courts: Article 177 as a Pre-federal Device, In: Sciarra, S. (ed.): Labour Law in the Courts, National Judges and the European Court of Justice, Hart Publishing, Oxford, p. 1-30.

Simitis, S. (2001): The Complexities of Living With and Interpretation Prerogative - Some Observations on an Imperfect Dialogue, In: Sciarra, S. (ed.): Labour Law in the Courts, National Judges and the European Court of Justice, Hart Publishing, Oxford, p. 291-300.

Employment Relationships Act (Zakon o delovnih razmerjih, Official Journal of the Republic of Slovenia, No. 42/2002).

Parental Protection and Family Benefits Act (Zakon o starševskem varstvu in družinskih prejemkih, Official Journal of the Republic of Slovenia, Nos. 110/06 - consolidated text, 114/06).

Public Guarantee and Maintenance Fund of the Republic of Slovenia Act (Zakon o Javnem jamstvenem in preživninskem skladu Republike Slovenije, Official Journal of the Republic of Slovenia, No. 78/06consolidated text).

Judgements of the Constitutional Court of the Republic of Slovenia:

No. 298/96, 11. 11. 1999 (Official Journal of the Republic of Slovenia, No. 98/99).

No. 49/98, 25. 11. 1999 (Official Journal of the Republic of Slovenia, No. 101/99).

No. 321/02, 27. 5. 2004 (Official Journal of the Republic of Slovenia, No. 62/04)

Judgements of the Supreme Court of the Republic of Slovenia:

No. VIII Ips 45/2001, 15. 1. 2002

No. VIII Ips 79/2004, 21. 12. 2004

No. VIII Ips 37/2005, 21. 6. 2005

No. VIII Ips 216/2005, 11. 4. 2006

No. VIII Ips 221/2005, 11. 4. 2006

Judgements of the Higher Labour and Social Court:

No. Pdp 451/2006, 31. 8. 2006

No. Pdp 1519/2004, 15. 9. 2005 
No. Pdp 1205/2004, 2. 2. 2006

No. Pdp 345/2004, 20. 10. 2005

No. Pdp 954/2005, 3. 3. 2006

No. Pdp 1174/2003, 24. 10. 2003

No. Pdp 1760/2003, 18. 12. 2003

The International Transport Workers' Federation and The Finnish Seamen's Union v. Viking Line ABP and OÜ Viking Line Eesti (Case No. C-438/05; the opinion of Advocate General Maduro, 23. 5. 2007)

Laval un Partneri Ltd v. Svenska Byggnadsarbetareförbundet and Others (Case No. C-341/05; the opinion of Advocate General Mengozzi, 23. 5. 2007)

www.us-rs.si (the Constitutional Court of the Republic of Slovenia)

www.sodnapraksa.si (case-law of Slovenian courts, including the Supreme Court, Department for labour and social disputes, and the Higher labour and social court)

www.curia.europa.eu (the ECJ) 


\title{
Diskussionsbericht zu Teil II
}

\author{
Diskussionsleitung: Juliane KOKOTT
}

Die Diskussion beschäftigte sich nach dem Koreferat von Ilešič abermals mit dem Fall Mangold. Moderatorin Kokott bemerkte zur Kritik an diesem Urteil, die sich unter anderem an der Kürze der Urteilsbegründung entzündet hatte, dass in der mündlichen Verhandlung die Bundesrepublik Deutschland angekündigt hätte, fortan das Alter nicht mehr zum alleinigen Unterscheidungskriterium zu machen, sondern eine Gesetzesänderung zu verabschieden, in der weitere Kriterien wie vorhergehende Arbeitslosigkeit Berücksichtigung fänden. Diese Ankündigung sei laut Kokott als ein praktisches Eingeständnis einer Vertragsverletzung seitens Deutschlands zu verstehen. Wenn jedoch ein Mitgliedstaat eine Vertragsverletzung zugestehe, erübrige sich eine allzu ausführliche Urteilsbegründung. Im Übrigen sei das Urteil Mangold im Ergebnis durchaus vertretbar.

Im Anschluss an das Koreferat von Kresal widmete sich die Diskussion der Frage, wie transnationale Arbeitskampfmaßnahmen oder ganz allgemein ausgedrückt transnationale Kollektivmaßnahmen von der Rechtsprechung des EuGH zu beurteilen seien. Denn auch hier zeige sich wieder das Problem des Ungleichgewichts gemeinschaftsrechtlicher Regelungszuständigkeit, da zwar der Binnenmarkt und das wirtschaftliche Agieren durch Dienstleitungsfreiheit und Niederlassungsfreiheit im Vertrag gewährleistet seien, Arbeitskampf- und Kollektivmaßnahmen jedoch auf ausschließlich nationalen Regelungen beruhten. Erörtert wurde diese Problematik anhand des beim Gerichtshof anhängigen Verfahrens Laval (Rs. 341/05). Den Ausgangspunkt der Diskussion bildete dabei der Schlussantrag des Generalanwalts, in dem gefordert wurde, dass alle Arbeitskampfmaßnahmen den Grundsatz der Verhältnismäßigkeit zu beachten hätten, was von den nationalen Gerichten zu prüfen sei. Dies wurde von anwesenden Gewerkschaftsvertretern entschieden abgelehnt, u.a. mit der Begründung, dass ein Messen von Arbeitskampfmaßnahmen am Grundsatz der Verhältnismäßigkeit der in vielen Mitgliedstaaten verfassungsrechtlich garantierten Koalitionsfreiheit widerspräche und das auf Verhandlungen der Sozialpartner und dem Abschluss von rechtlich verbindlichen Kollektivverträgen beruhende Arbeitsmarktmodell grundlegend ändern würde. Auch Bercusson sah bezüglich der Anwendung des Grundsatzes der Verhältnismäßigkeit bei der Prüfung der rechtlichen Zulässigkeit von Arbeitskampfmaßnahmen auf transnationaler Ebene erhebliche Probleme. Zwar sei es verständlich, dass einige Stimmen am EuGH versucht sein könnten, dieses wohlbekannte Kriterium auf Kollektivmaßnahmen anzuwenden. Allerdings bestünde dann die Gefahr einer zutiefst uneinheitlichen Rechtsprechung in den Mitgliedstaaten, die zu einer wahren Prozessflut beim EuGH führen würde. Wenn schon verschiedene Gerichte in ein und demselben Mitgliedstaat die Zulässigkeit einer Arbeitskampfmaßnahme aufgrund der vagen und stark auslegungsbedürftigen Verhältnis- 